\title{
Labour standards and technological upgrading: competitive challenges in the global football industry
}

\author{
Khalid Nadvi \\ Institute of Development Policy and Management (IDPM), \\ School of Environment and Development (SED), \\ University of Manchester, Arthur Lewis Building, \\ Oxford Road, Manchester M13 9PL, UK \\ E-mail: khalid.nadvi@manchester.ac.uk
}

\begin{abstract}
Football manufacturing is a billion dollar industry heavily dominated by major global brands. Over the past 15 years there have been significant changes in the geographies of production with China consolidating its position as the number one football producer taking market share from Pakistan, the second largest producer. On the end market side, newly emerging markets have increased in importance but the EU and the USA have remained dominant. Over the past 15 years global football manufacturing has faced concerns on labour standards compliance and experienced distinct patterns of product and process upgrading. Using the analytical frameworks of global value chains and technological capabilities and learning, this study considers the challenges arising from technological upgrading and labour standards compliance within the global football industry and its implications for local producers.
\end{abstract}

Keywords: global production networks; technological learning; clusters; sports goods; China; Pakistan; global value chains; GVCs.

Reference to this paper should be made as follows: Nadvi, K. (2011) 'Labour standards and technological upgrading: competitive challenges in the global football industry', Int. J. Technological Learning, Innovation and Development, Vol. 4, Nos. 1/2/3, pp.235-257.

Biographical notes: Khalid Nadvi is a Senior Lecturer in Development Economics at the University of Manchester. He is a Political Economist and works primarily on issues relating to trade and industrial development with a focus on small enterprise clusters, global value chains, global standards, technological upgrading and corporate social responsibility. His earlier research explored the relationship between local clusters and global value chains, and the role of labour and quality standards in the local and global governance of trade and production ties. His sectoral expertise lies in the global apparel, sports goods, and medical appliances industries, drawing on evidence from South and South-East and East Asia. He currently leads an ESRC funded international network on the impact of the emerging powers (China, India and Brazil) on the governance of global labour and environmental standards.

\section{Introduction}

One of the possible 'losers' of the 2010 Football World Cup staged in South Africa was the reputation of Adidas' 'Jabulani' match ball. Developed through a new design that 
involved the thermo-moulding of eight curved panels to produce the perfect sphere, the ball was supposed to be the most aerodynamic of its kind. It came in for criticism, however, from players, the media and football supporters for its often unpredictable flight ${ }^{1}$. The Jabulani match balls were manufactured for Adidas in China. Till the 1990s the World Cup match balls were hand-stitched and produced in Pakistan. These shifts, both in terms of the geographies of production and product and process upgrading, are two of the three key factors that have shaped the dynamics of the global football industry over the past 15 years. The third relates to compliance with international labour standards, most notably on child labour. Pakistan and China are the leading centres for production in an industry dominated by major global sports good brands. Using the analytical frameworks of global value chain (GVC) analysis and technological learning, this paper considers the challenges arising from technological upgrading and labour standards compliance in the global football industry and its consequence for local producers. The mechanisation of production and the economies of scale observed in China imply that Pakistani producers (and workers) need to improve their 'game' if they are to retain their global position in this industry.

The paper draws on primary evidence, including detailed qualitative firm interviews in Pakistan and China, as well as with the leading global sports goods brands, undertaken over a period of over two years between 2008 and $2010^{2}$. The paper is set out as follows. The next section outlines the analytical frameworks of GVC and technological capabilities and learning. Section 3 provides a descriptive overview of the global football sector and the geographies of production. It reviews changes in end markets and shifts in trade dynamics between the leading locations of football manufacturing in the world. Section 4 considers the nature of labour standard challenges. Section 5 outlines technological upgrading in both product and process activities. Section 6 considers the implications of technological upgrading and standards compliance for GVC linkages in China and Pakistan. Section 7 concludes by assessing the implications of these developments for Pakistani producers to improve their ability to compete with China.

\section{GVCs and technological learning}

One of the key developments in the recent literature on industrial organisation has been on the related concepts of GVC and global production networks (GPN) (Bair, 2005; Gereffi et al., 2005; Kaplinsky, 2005; Henderson et al., 2002; Coe et al., 2008) ${ }^{3}$. GVCs are described as an input-output framework that provide a detailed understanding of how goods and services are designed, produced, delivered, retailed and even recycled. The GVC framework provides a systemic basis to assess how value is created along the chain, and how it is expropriated. Central to the analysis is the role of 'lead' firms that organise the chain [what Rugman and D'Cruz (1997) refer to as 'flagship firms' in the business literature and Ernst (2002) describes as 'network flagships']. Gereffi (1994) initially distinguished between 'buyer' and 'producer' driven lead firms, the former being agents that undertook no production activity but had core competence in areas such as design, marketing and/or retail. The classic examples were the global shoe or garment sectors where the leading international brands and retail houses sourced products from dispersed independent suppliers. Producer driven chains were to be found in relatively more capital-intensive sectors, such as automobiles and electronics, where lead firms held core competence in production and design. 
The buyer/producer distinction of lead firms has been questioned over time. In garments, for example, the emergence of 'fast fashion' has meant that some leading international brands (such as Inditex) engage directly in production while also sourcing from independent suppliers (Tokatli, 2008). In electronics, many leading global brands no longer engage in production and instead rely increasingly on first tier contract manufacturers (Sturgeon, 2002). Consequently in a seminal article Gereffi et al. (2005) argued that a more appropriate taxonomy of GVCs could be found by using transaction costs analysis. This distinguished the governance or organisation of GVCs according to the complexity of the transaction between lead firms and their suppliers, the capabilities of the suppliers, and the extent to which the transaction could be easily codified. This approach suggested distinct forms of governance relationships between lead firms and suppliers reflecting the distinct power asymmetries within the relationship. Thus, they argued, GVC relationships could take one of five governance forms, from market based transactions, to modular, captive, relational and finally hierarchical arrangements. Although the Gereffi et al. (2005) framework has been critiqued on the grounds that it is relatively static, and that in many sectors multiple forms of governance arrangements exist (Coe et al., 2008; Gibbon and Ponte, 2008), it remains a useful analytical tool in considering the nature and basis of power of lead firms within GVCs.

The nature of GVC governance can significantly impact on the ability of producers along the chain to upgrade. Humphrey and Schmitz (2002) distinguish the following forms of upgrading within a GVC context: process upgrading, product upgrading, functional upgrading, and chain upgrading. The ability of local producers within the chain to engage in these distinct forms of upgrading are, it is argued, conditioned by the ways in which such firms are inserted into the chain and the power asymmetry that marks their ties with the lead firm. Knowledge flows and the transfer of know-how and capabilities are seen to flow vertically through the chain, depending on the nature of governance ties. It is only in more modular forms of GVC governance, where power asymmetries are less sharp, where supplier capabilities are high and where the transactions are complex and ability to codify is also high that knowledge flows can also come from suppliers to lead firms, often through extensive user-producer based interactions and co-engagement. In contrast, in captive chains patterns of upgrading, learning and knowledge flows are likely to come from the lead firms and move down the chain to their dispersed suppliers.

One of the difficulties with the GVC framework is that while it provides an extremely useful analytical tool for understanding the dynamics of specific industries, it remains relatively weak in its conceptualisation of how technological progress, learning and capabilities are acquired. There is little understanding within the framework of the agency of individual firms in developing capabilities or the wider institutional context through which firms learn and technologically progress. This point has been noted recently by a number of scholars (Morrison et al., 2008; Sun and Zhang, 2009; Sato and Fujita, 2009). One critical aspect of this challenge is that the GVC framework is weak in terms of considering how learning takes place within firms, and how capabilities are acquired. There is of course a very rich and well understood literature on technological capabilities (Lall, 1992; Bell and Pavitt, 1993; Ernst and Kim, 2001) and on systems of innovation (Nelson, 1992; Edquist, 1999; Cook et al., 1997; Mytelka, 2000). This literature has provided insights on how capabilities are acquired within firms and across regions, and how innovative practices can systematically develop, and be socially embedded, within national and regional systems of innovation. 
Understanding the capabilities of suppliers is central to considering how governance operates within a GVC. But capabilities are also dynamic and influenced by both intra-firm, intra-chain and extra-chain factors. As Morrison et al. (2008, p.41) have argued, in interrogating the relationship between technological capabilities and the GVC governance framework it is critical to first challenge the 'rather fuzzy' understanding of upgrading provided by the GVC literature. As they state, upgrading is fundamentally about enhancing capabilities, and this requires purposive action by firms. However, much of the GVC literature tends to confuse the causality between 'upgrading' and 'innovation', with the two concepts often being 'used interchangeably' (ibid, p.45). This criticism is not dissimilar to the challenge raised by Bell and Albu (1999) about the understanding of upgrading within much of the literature on clusters in developing countries. Moreover, the primary focus on the role of the lead firms and their governance structure as the key transmitters of knowledge, know-how and capabilities within GVCs tends to underplay the importance of the capabilities of suppliers along the GVC and their absorptive capacities to acquire and build on incremental and new knowledge. This implies a need for greater awareness of how learning takes place within suppliers, and also how suppliers within the chain move from what Bell and Albu (1999) refer to as 'knowledge using' to 'knowledge changing' capabilities. The former points to capabilities that enhance the capacity of firms to efficiently appropriate and use technologies, especially in process functions. The latter points to knowledge and capabilities that allow firms to innovate and develop the capacity to generate change.

While understanding the knowledge-using and knowledge-changing capability of suppliers requires more in-depth analysis of technical capabilities at the level of firms (and for that matter clusters and regions), capability enhancement is not solely an outcome of actions by the suppliers. The chain, and the nature of governance within the chain, also influences this process. In an earlier study, Nadvi and Halder (2005) described how insertion within the GVC impacted on the ability of local cluster producers in the Sialkot surgical instruments industry to acquire capabilities, especially capabilities related to process upgrading around compliance with quality assurance standards. However, knowledge-changing capabilities did not emerge through the GVC nor were they generated by local extra-GVC institutions or innovation and learning systems. Consequently, the Sialkot surgical instrument cluster had reached a technological plateau unable to acquire the skills and know-how necessary to bring about new product development and move into higher value added surgical instruments that required the capability to not only undertake metal working but also the capacity to use new materials (such as ceramics) and new technologies (including optical and fibre-optic processes). This inability to innovate was a direct outcome, according to Nadvi and Halder (2005), of the nature of GVC ties linking the cluster to global buyers and the failure of regional innovation systems to evolve.

In sum, the GVC approach provides a useful tool to understand how local producers are linked into global markets, and how lead firms can organise the complex chains that connect such producers. However, the GVC framework is relatively weak in its understanding of upgrading, and of how capabilities are acquired and learning takes place within the firm and along the chain. GVC governance is one critical factor in understanding this process, but it is also important to understand the agency of supplier firms in acquiring capabilities as well as the local systems of learning (or extra-chain knowledge milieus) within which firms in GVCs are also located. Finally, moving from knowledge-using to knowledge-changing capabilities may require learning from outside 
the local knowledge milieu and the chain in order to develop new forms of tacit knowledge and capabilities. The challenge from Morrison et al. (2008) is therefore timely. However, they provide no empirical evidence of how technological capabilities, learning and GVC insertion and governance are linked.

\section{The global football industry: an overview of the geographies of production}

\subsection{Trends in global markets and global trade}

Football is now acknowledged as the global sport in terms of popularity. International trade in inflatable balls (of which footballs are the largest single component) is substantial, accounting for US\$1.15 billion in 2008 (UN Comtrade, 2010), and trade volumes rose by $240 \%$ in nominal terms between 2001 and 2008 (ibid.) $)^{4}$. The growth in international trade in footballs is underlined by the marketing cache of international tournaments (most notably the football World Cup, the European Cup, and the Olympics), worldwide media coverage especially of the UK Premier League and the European Champions League, and the draw of the leading international football clubs and star players. Thus, football has acquired a cultural significance at the global level that cannot be matched by any other sport (Goldblatt, 2006).

At the same time the industry is increasingly dominated by leading international sports good brands. The main actors in the sector are Adidas, Nike, Puma, and Mitre-Pentland. Adidas and Nike are the key players. According to one web-based source, in 2009 Adidas accounted for 34\% of the global football business with sales of US\$1.57 billion from football related merchandising, while Nike has annual revenues of U\$1.7 billion from footballs and football related products (http://www.sportskeeda.com/2010/06/11/adidas-vs-nike-the-biggest-world-cup-match/). Adidas and Nike compete extensively with each other in product development and in marketing, especially through commercial endorsements with major clubs, players and leading tournaments. The two leading brands have also consolidated their position in the industry by acquiring other major sports good brands. Thus, Adidas bought Reebok for US\$3.8 billion in 2005 and Nike acquired Umbro for US\$580 million in 2007 (Morris, 2007).

Footballs are differentiated by price, quality, performance and market niches. At the top end of the industry are professional match balls. These are developed and sold by the major brands and used in leading international and regional tournaments and by professional teams in the major domestic football leagues. Below match balls come training balls - which are somewhat lower in quality but still used by football professionals and leading teams. Training balls are also more widely available as retail items. Training balls are also manufactured for the leading brands through their supply chains, although unlike match balls there are a wider number of brands and distributors that source training balls. Within training balls there are a wide variety - differentiated by price and performance. The top end training balls are the branded replicas of match balls. At the lower end are non-branded and lower priced balls. Below training balls come a number of lower quality balls including recreational balls, promotional balls (sourced by non-sports brands as part of marketing strategies), laminated balls (that are not based on 
PU or PVC panels and thus do not require any stitching) and finally toy balls (usually panel based and stitched but smaller in size than a normal football).

Prices vary sharply. Top end branded match balls retail at over US\$130 per unit whereas branded replica recreational balls and lower end training balls can be sold for around US\$15 to US\$20 per unit. Non-branded PVC recreational balls can be sold for US\$5 to US\$10 per unit. While the major brands dominate the top end of the industry, they are not the sole marketing channels through which football producers engage with global markets. Manufacturers supply non-sports good brands (for promotional balls), football clubs and federations (for training balls), leading international retailers including the major global supermarkets such as Walmart, Tesco and Carrefour (for both training, recreational, laminated and toy balls) as well as a wide array of non-branded distributors and retailers who supply regional and lower end markets across the world (for both medium and lower quality footballs).

While the brands dominate the industry, they do not manufacture footballs. As in many other labour-intensive manufacturing sectors, the brands co-ordinate a large and widely dispersed group of global suppliers who act as original equipment manufacturers (OEM). The primary centres of production are China, Pakistan and Thailand. Together these three countries accounted for $70.3 \%$ of total global exports of inflatable balls in 2009 (UN Comtrade, 2010). However, as Figure 1 below indicates, there has been a dramatic shift in fortunes across the three locations in recent years. Pakistan has seen its market share fall sharply (from $23.2 \%$ in 2004 and $23.0 \%$ in 2006 to $13.2 \%$ in 2009), while China has experienced consistent growth $(28.9 \%$ in 2004, 35.4\% in 2006 and 50.5\% in 2009). The third largest producer, Thailand, has also experienced a notable decline, from $9.8 \%$ of global exports in 2004 to $6.6 \%$ in 2009 (ibid.).

Figure 1 Share of global exports of inflatable balls from the major manufacturing countries, 2004-2009 (\%) (see online version for colours)

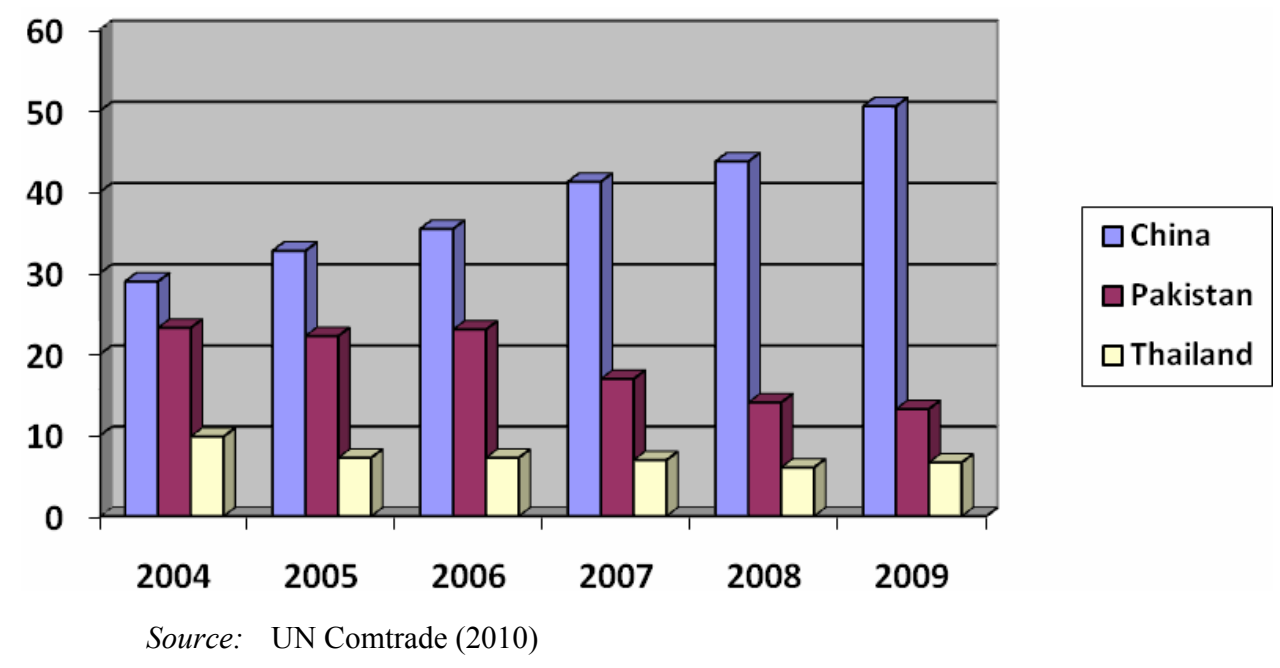

Pakistan's sharp decline in exports for 2009, a fall of 26\% from 2008 export levels, may be a temporary glitch. Export trade in footballs peak in even years when the major international tournaments (the World Cup, the European Championships) take place. 
These lead to added global demand for footballs, especially for recreational replicas of tournament match balls, and also a growth in demand for promotional balls used by non-sports goods brands as marketing tools at the time of leading international tournaments. Thus, both Pakistan and Thailand experienced higher export volumes in even years (with the exception of 2008 for Pakistan). These year-on-year increases can be substantial. Pakistan's export levels in 2004 were 64\% higher than those in 2003, and similarly export volumes in 2006 (at the time of World Cup held in Germany) were 22\% above those in 2005 (ibid.). Such large fluctuations clearly imply the need for flexibility on the part of local producers, to be able to quickly ramp up production for higher volumes in peak years. Interestingly, China has seen export volumes grow year on year and at a substantial pace until 2009. Annual growth rates in export volumes from China averaged a phenomenal $23 \%$ during the period 2003-2008, although growth rates were higher for even years, again underlining the biannual seasonality in global football demand.

What is clear is the consolidation of China as the leading manufacturer of footballs, at the expense of Pakistan. Pakistan's decline is especially marked since 2006. During the four year period 2006-2009, Pakistan's football export levels almost halved, falling from US\$226 million in 2006 to US\$118 million in 2009. During the same period Chinese exports of inflatable balls rose from US\$348 million to US\$454 million (ibid.). One factor that accounts for the rapid fall in football exports in Pakistan in 2007 was the fact that the leading buyer from Pakistan, Nike, stopped sourcing from Sialkot in late 2006 in response to compliance related allegations associated with possible leakages of production by their then main supplier in Sialkot to home-based units. Nike did return to the Sialkot cluster in 2007, sourcing, albeit in smaller volumes, from a new supplier. Yet, the fact that football export levels from Pakistan have not only not recovered to their peak of 2006, but declined each year between 2007 and 2009 suggests that there may be a more substantive erosion of competitiveness, and of markets, for Pakistani producers.

The nature of end markets has changed much less dramatically. The two leading global markets are the European Union (EU) and the USA. The EU is the largest single market, with $27.8 \%$ of total global inflatable ball imports in 2009 , while the USA accounted for $19.8 \%$ of total global imports. While the EU's import share has remained relatively consistent, that of the USA has declined (from $23.6 \%$ in 2004). On the other hand, newly emerging markets (particularly in Latin America but also in East and South East Asia) have grown although they command a much smaller share of the global imports of football (ibid.). The increasing importance of new end markets reflects the growing global popularity of the sport, and the expansion of sports goods retailing and the major sports goods brands into newly emerging markets. Thus, the main players in these 'new' markets are often the traditional global brands based in developed countries. For example, Nike considers China not only its major sports goods supplier but also its leading end market (Nike interviews, Boston, January 2008; Guangzhou May 2010).

While both China and Pakistan supply all the major sports goods brands and non-sports brands as well as leading global retailers alongside a myriad of independent distributors, their end markets differ quite sharply. China's main market has consistently been the USA. Pakistan's main market has remained the EU, accounting for approximately half of Pakistan's total exports of footballs during the period 2004-2009 (see Table 1). 
Table 1 Leading markets for Chinese and Pakistan inflatable ball exports, 2004-2009

\begin{tabular}{|c|c|c|c|c|c|c|}
\hline \multirow{2}{*}{$\begin{array}{l}\text { Main } \\
\text { markets }\end{array}$} & \multicolumn{2}{|c|}{2004} & \multicolumn{2}{|c|}{2006} & \multicolumn{2}{|c|}{2009} \\
\hline & China & Pakistan & China & Pakistan & China & Pakistan \\
\hline $1 \mathrm{st}$ & $\begin{array}{c}\text { USA } \\
45.9 \%\end{array}$ & $\begin{array}{c}\text { EU } \\
48.0 \%\end{array}$ & $\begin{array}{c}\text { USA } \\
36.7 \%\end{array}$ & $\begin{array}{c}\mathrm{EU} \\
49.8 \%\end{array}$ & $\begin{array}{c}\text { USA } \\
27.9 \%\end{array}$ & $\begin{array}{c}\text { EU } \\
51.5 \%\end{array}$ \\
\hline 2nd & $\begin{array}{c}\mathrm{EU} \\
19.2 \%\end{array}$ & $\begin{array}{c}\text { USA } \\
11.4 \%\end{array}$ & $\begin{array}{c}\mathrm{EU} \\
22.1 \%\end{array}$ & $\begin{array}{c}\text { USA } \\
11.1 \%\end{array}$ & $\begin{array}{c}\mathrm{EU} \\
19.4 \%\end{array}$ & $\begin{array}{l}\text { USA } \\
9.7 \%\end{array}$ \\
\hline $3 \mathrm{rd}$ & $\begin{array}{l}\text { Japan } \\
4.2 \%\end{array}$ & $\begin{array}{c}\text { Mexico } \\
6.4 \%\end{array}$ & $\begin{array}{l}\text { Japan } \\
4.0 \%\end{array}$ & $\begin{array}{c}\text { Mexico } \\
8.8 \%\end{array}$ & $\begin{array}{l}\text { Japan } \\
3.4 \%\end{array}$ & $\begin{array}{l}\text { UAE } \\
5.7 \%\end{array}$ \\
\hline 4 th & $\begin{array}{c}\text { South } \\
\text { Korea } \\
2.3 \%\end{array}$ & $\begin{array}{l}\text { UAE } \\
4.5 \%\end{array}$ & $\begin{array}{c}\text { South } \\
\text { Korea } \\
3.0 \%\end{array}$ & $\begin{array}{l}\text { UAE } \\
5.3 \%\end{array}$ & $\begin{array}{c}\text { Kazakhstan } \\
2.6 \%\end{array}$ & $\begin{array}{c}\text { Mexico } \\
4.0 \%\end{array}$ \\
\hline 5 th & $\begin{array}{l}\text { UAE } \\
2.2 \%\end{array}$ & $\begin{array}{l}\text { Japan } \\
3.1 \%\end{array}$ & $\begin{array}{l}\text { Chile } \\
2.2 \%\end{array}$ & $\begin{array}{l}\text { Japan } \\
2.4 \%\end{array}$ & $\begin{array}{c}\text { Russia } \\
2.3 \%\end{array}$ & $\begin{array}{c}\text { South } \\
\text { Africa } \\
3.0 \%\end{array}$ \\
\hline 6th & $\begin{array}{l}\text { Chile } \\
1.7 \%\end{array}$ & $\begin{array}{l}\text { Chile } \\
2.4 \%\end{array}$ & $\begin{array}{l}\text { UAE } \\
2.2 \%\end{array}$ & $\begin{array}{l}\text { Turkey } \\
2.1 \%\end{array}$ & $\begin{array}{c}\text { Saudi Arabia } \\
2.2 \%\end{array}$ & $\begin{array}{c}\text { Turkey } \\
2.8 \%\end{array}$ \\
\hline
\end{tabular}

Source: UN Comtrade (2010)

Moreover, there is an interesting story with regards to emerging markets. China has seen its export markets diversify in recent years, with the US accounting for $27.9 \%$ of total exports in 2009 as compared with $45.9 \%$ in 2004. New emerging markets for China include countries such as Chile, Brazil, Russia, South Korea and the Arab Gulf states. Brazil, for example, accounted for $0.3 \%$ of total Chinese inflatable ball exports in 2004, $0.7 \%$ in 2006 and $2.1 \%$ in 2009 (UN Comtrade, 2010). Pakistan, too has diverse end markets for its footballs, with key emerging markets in Mexico, United Arab Emirates, Turkey and South Africa. The importance of these emerging markets as a whole is borne out in Table 2. Amongst the top ten exports markets for both China and Pakistan during this period, the share of exports to emerging markets has clearly and consistently grown for both countries. Moreover, as a whole these emerging markets count for a significant overall share of total exports, outstripping exports to the USA from Pakistan.

Table 2 China and Pakistan's inflatable ball exports to emerging markets, 2004-2009

\begin{tabular}{ccc}
\hline $\begin{array}{c}\text { Share of total exports to emerging markets } \\
\text { (for top ten export markets only) }\end{array}$ & China & Pakistan \\
\hline 2004 & $8.4 \%$ & $19.3 \%$ \\
2006 & $10.9 \%$ & $20.1 \%$ \\
2009 & $15.1 \%$ & $21.8 \%$ \\
\hline
\end{tabular}

Note: Emerging markets are defined as non-OECD economies but includes Chile,

Mexico and South Korea which are OECD member states.

Source: UN Comtrade (2010)

These distinct patterns of exports from China and Pakistan reflect in part the different kinds of footballs that the two countries produce. While both manufacture across the full range of footballs outlined above, Pakistan has historically been known as the leading producer of high quality hand-stitched match balls, although it also produces lower quality hand stitched training, recreational, promotional and toy balls. China on 
the other hand primarily produces lower to medium quality machine-stitched training, recreational, promotional and toy balls as well as laminated footballs. This is the volume end of the global industry and China's rapid expansion as the leading football producer is associated with the higher productivity levels and improving quality of machine stitched footballs. Moreover, process and product upgrading has also meant that China is now the main supplier of the highest quality top end professional match balls produced for the two major global brands, Adidas and Nike. Thus, it has encroached into Pakistan's niche in the high end professional match ball market.

\subsection{Football production in China and Pakistan}

According to one estimate there are some 200 football manufacturing suppliers in China (Global Sources, 2006). These are primarily located in two areas. First, in Guangdong province where large foreign owned (primarily Taiwanese and Hong Kong) factories produce a wide range of sports goods. Second, in Jiangsu province where there are a number of smaller producers that focus primarily on footballs and other inflatable balls. Within Jiangsu there are specific clusters of football producers, especially in Wuxi, Nanjing and Haimen. Moreover, the vast majority of football manufacturing units in Jiangsu are not FDI-based factories. Most have grown out of former town and village enterprises (TVEs), state owned enterprises and small private family workshops. Both regions produce machine-stitched footballs. However, China's relatively smaller production of hand stitched balls comes largely from Jiangsu province, in particular from small and medium sized factories in the Haimen region.

There is also a marked difference in terms of factory size as well as production scope between the two regions in China. Many of the factories in Guangdong employ over 1,000 workers and usually produce a wide range of sports goods and equipment. Some of the largest firms (the biggest football manufacturing firm in China employs over 7,000 workers) are highly specialised in a range of balls and produce for the major global brands, in some cases maintaining separate production lines for both Nike and Adidas. In contrast, the Jiangsu based firms are considerably smaller (with a workforce of between 100 to 300 workers), only produce balls, and often act as suppliers to traders or in some cases as second-tier suppliers to major brands. Finally, as effective wages and labour turnover have begun to rise in recent years in the Pearl River delta, some large foreign owned plants have moved from Guangdong to new 'Greenfield' sites in inner provinces (such as Jiangxi) where wage rates are lower and regional fiscal incentives to attract new investment significant.

Compared with the relatively dispersed pattern of production observed in China, football manufacturing in Pakistan is found solely in and around the city of Sialkot in Northeastern Punjab. Here, a cluster of nearly 400 small and medium-sized manufacturing units employ approximately 30,000 workers in total (Nadvi, 2004; UNIDO, 2008). The cluster has a long history that dates back to the colonial era. Within the cluster a group of some 30 medium to large firms dominate. However, Pakistan's large firms are much smaller compared to those in China, with only a handful of firms in Sialkot directly employing more than 500 workers. Production is undertaken within the confines of the city of Sialkot, although football stitching can be found in rural villages within a 50 kilometres radius of Sialkot.

There is also a sharp distinction in the nature of the production process across China and Pakistan. Chinese footballs are primarily produced in large factories with mechanised 
production lines using machine stitching technology. The PU and PVC based panels are usually made in-house and panels subsequently cut and printed. The panels are then stitched by machine and bladders and valves inserted before the final balls are tested and packed. In Guangdong in particular there is a preponderance of migrant workers who live within factory based dormitories, and wage levels are influenced by the local legal minimum wage regulations. In Pakistani football factories panel cutting and printing is undertaken in-house and is partially mechanised. Stitching, however, is wholly undertaken manually. Moreover stitching is rarely carried out within the confines of the factory - instead it is usually put out through subcontractors to specific stitching units where individual stitchers stitch balls on a piece rated basis. Stitched balls are then returned to factories for quality assurance, final assembly and packaging.

Productivity levels differ sharply between China and Pakistan, reflecting the distinct technological forms that dominate the two locations. Factory based machine stitchers in China produce around 40 footballs a day (usually working a 10-hour shift for six days a week). In contrast, full-time hand stitchers in Pakistan stitch between four to five balls a day (again working six days a week for an 8-hour shift per day). Sialkot's football stitchers, unlike their Chinese counterparts, are not migrant workers. They come from Sialkot and its rural hinterland. For many of Sialkot's stitchers, football stitching was seen as an off-farm activity to augment other sources of rural livelihoods. Stitchers working for the larger manufacturers in Sialkot have now graduated into full-time employment. In Sialkot, stitching is carried out by men and women, although men tend to get to work on the higher quality match balls as these are made with thicker PU panels and thus require more force and strength to carry out the hand stitching of panels. Consequently, male stitchers tend to get a higher piece rate wage. Most Pakistani stitchers have very low levels of education (and many are illiterate) and average earnings from football stitching rarely exceed US\$3.00 a day in Sialkot. Wage levels in football factories in China were considerably higher than those reported in Pakistan, at around US\$10 to US\$12 a day for factories in Guandong province and around US\$7 a day in the Jiangsu region ${ }^{6}$.

\section{Labour standard challenges}

A key factor in recent developments within the global football manufacturing industry has been the pressures associated with labour standards compliance. Given the global cultural standing of football, and the role of major global brands in the industry, meeting international labour standards is of great significance. This has been most sharply and most widely felt in relation to the use of child labour in football stitching in Pakistan ${ }^{7}$. In 1995 and 1996 a series of media exposes revealed the presence of child workers in Sialkot, especially where work was being undertaken in home-based units. A very rapid response ensued, driven both by local producers through their trade body the Sialkot Chamber of Commerce and Industry (SCCI), and by the leading brands through the World Federation of Sporting Goods Industry (WFSGI). In 1997, the Atlanta Agreement was signed which provided a mechanism to ensure credible monitoring against child labour by the International Labour Organization (ILO) and the implementation of a number of social protection initiatives geared to tackle the root causes of child work - poverty, low incomes and poor education provisioning within the region. Funding for these initiatives came from a range of international donors, including the USA (which 
co-funded with the local industry the ILO's monitoring programme) and the UK (which financed international NGO efforts on education improvements). The major brands required their suppliers to subscribe to the monitoring programme and by 2003 some 90 local manufacturers (and all the leading OEM suppliers to the leading global brands) were being monitored by the ILO inspectors (Nadvi, 2004, Lund-Thomsen and Nadvi, 2010).

The challenge of child labour in Sialkot resulted in a significant shift in production arrangements. While stitching continued to remain a manual task paid on a piece rated basis, production moved into designated stitching centres which could be more easily monitored both by the ILO and by the major brands. These centres were independent sub-contractors to the OEM suppliers. In 2003-2004 external funding for child labour monitoring and social provisioning ended and these functions were taken over by local actors. The leading international actors (the ILO, UNICEF and the UK's Save the Children Fund) left the cluster with their tasks taken over by local public and private bodies and funded primarily by local producers. In 2006, the largest buyer from the Sialkot cluster - Nike - stopped sourcing from its sole supplier (and at the time the largest producer in Sialkot) on the grounds of alleged leakages of production from the designated stitching centres. Nike returned to the cluster a year later sourcing from a new supplier but with one major difference from its previous arrangement. The fear of further potential leakages led Nike to demand that its new supplier would not use subcontractors for stitching, and that all production (including all stitching work) had to be undertaken within the supplier's factory premises. Factory-based production also implied for Nike a move towards the use of permanent wage employees who were to be provided the full legal provisions under Pakistani labour laws (Lund-Thomsen and Nadvi, 2010).

Although child labour has not been an issue in football production in China, labour standards challenges, while not as acute as those faced in Pakistan, have been relevant to the Chinese football manufacturing sector. These have related to issues of working conditions in football factories as well as overtime and the limits to collective bargaining rights. In addition, workers in football manufacturing in the Guangdong region are predominantly migrant workers who usually live in dormitories within the factory premises and as migrant workers do not have local 'hukou' (or citizenship) rights which limit their ability to access healthcare and other social provisioning. These issues are not dissimilar to those faced in other labour-intensive manufacturing industries in the Pearl River Delta (Chan, 2003, 2010; Pun, 2005; Sum and Ngai, 2005). There is also evidence of labour strife within the football manufacturing sector. The major brands have sought to address these concerns by requiring their suppliers to strictly comply with the brands' individual codes of conduct and corporate social responsibility norms.

In addition, there have been questions on the use of prison labour in Chinese football production. While prison labour is not illegal in China, US law restricts the import of goods manufactured by prison labour. During the late 1990s questions were raised about the possible use of Chinese prison labour in the football manufacturing supply chains of leading brands (see http://news.bbc.co.uk/1/hi/124522.stm). Subcontracting of football production by the main OEM suppliers in China to smaller units, especially in response to peak demand, is not uncommon. This raises concerns on the possibility of leakage of production to prisons, and to home-based units where underage labour may be present where such subcontracting practices are not properly audited (Fair Labour Association, 2010). One consequence of the challenge raised by the possibility of leakage of production to prison workers has been a greater concern by the brands to have more 
independent and in-house monitoring of their supply chains and to move increasingly to sourcing from suppliers that have the capacity to undertake all production in-house.

\section{Upgrading and new product and process technologies}

Research on the global football industry, and in particular on the Sialkot cluster, has tended to focus almost wholly on the child labour issue and the consequent implementation of the Atlanta agreement (Husselbee, 2000; Kolk and Tulder, 2001; Nadvi, 2004, 2008; Khan, 2007; Khan et al., 2007; Seigmann, 2008; Lund-Thomsen and Nadvi, 2010; Lund-Thomsen and Khan, 2011). What has not been studied at any length is the nature of technological change within the industry, and its consequences for, inter alia, the geography of production.

It is worth reflecting briefly on the developments in football product and process technologies. The modern football was historically made of leather and manufactured by hand in the UK and in parts of Europe. The main technical concerns in football production related to improving the spherical nature of the ball and to reduce its ability to absorb water. This led over time in two key innovations. First the development of the 32 panel ball (consisting of 20 hexagonal and 12 pentagonal panels) in the early 1960s by the Danish company Select Sports, which resulted in a more realistic sphere. Second the gradual replacement of leather by less porous synthetic materials in the manufacturing of panels during the 1960s through to the mid 1980s. It was not, however, until 1986 that the first fully synthetic polyurethane (PU) football was produced for the 1986 World Cup tournament in Mexico. The vast majority of match, training, recreational and promotional footballs manufactured today are made solely from synthetic leather substitutes and the 32 panel ball remains the most common.

During the past decade a key area for technological improvement in footballs has been associated with advances in the materials used in making ball panels - from higher quality woven and non-woven PU, to improved poly vinyl chloride (PVC) and thermoplastic polyurethane (TPU). Within each of these materials there are differing qualities, often linked to the kinds of fabric, foam, rubber and backing materials used in the construction of panels. PU has tended to be the best material in terms of ball construction - being resilient, highly water resistant and providing the best performance and aerodynamic qualities. PVC has been a cheaper material and one that is often linked with negative environmental externalities. However, PVC is one of the most common materials used to produce footballs and an area where material development has improved. TPU is emerging as an important material that is beginning to replace PVC especially with the mass market segment of training and recreational balls.

While improved materials impact on the aerodynamic qualities of footballs, and reduce their absorption of water as well as lower costs, product development has also focused on the construction of the perfect sphere. Over the past five years this has seen the emergence of footballs manufactured with fewer interlocking panels. In 2006 Adidas introduced the first 14 panel thermo-moulded football for the 2006 World Cup in Germany (called the Teamgeist ball). The reduction in panels meant that the new ball more clearly formed a perfect sphere, with less resistance and thus offering improved flight and performance. The nature of the panels used also provided more opportunities for top players to spin the football, thus improving their ability to curve the ball in flight making it more difficult for goalkeepers to predict directions. With the traditional 
32 panel ball there is the possibility for greater air friction arising from the points and threading that stitch the panels together. The 2006 thermo-moulded ball reduced this by reducing the number of panels and by doing away with the need for stitching the panels through the use of thermo-moulding technologies that bonded the panels together under high temperatures. The 2010 Adidas Jabalani ball took this process further by reducing the number of panels (from 14 to 8 ) and by making the panels themselves curved rather than the traditional flat panels. Thus the Jabalani ball was considered by Adidas to further improve the aerodynamics, flight and performance qualities of its 2006 teamgeist ball.

It is clear, therefore, that product development upgrading in the football sector is closely related to process development upgrading. There are a number of aspects to this. First, the traditional 32 panel football used to be stitched by hand. In 1996, the Taiwanese owned firm Top Ball, based in Dongguan, China, patented the use of machine stitching technologies to manufacture footballs using glue-coated nylon thread. This development radically transformed production and was copied widely within China by other manufacturers. This process innovation was critical to the rapid growth of the export football manufacturing sector in China.

For the premium match balls, hand stitching was still considered to be of higher quality due to the improved tension of the stitch compared with what could be achieved through machine stitching. Thus at the top end, hand-stitched balls were considered more reliable and more aerodynamic then machine-stitched balls. Consequently, one of the key features of Sialkot has been the wholly non-mechanised process of neo-artisanal hand-stitching. In fact, it is the quality of hand stitching to be found within Sialkot that has allowed the cluster to continue to be a key supplier of the premium segment of the match and training ball market, and to ensure that the leading global brands continue to source from there. At the same time, as the trade data underlines, export production has grown sharply in China where machine stitching undertaken along factory-based assembly lines is the dominant form of production. Machine-stitched balls do not have the same resilience and qualities as premium hand stitched products, but that appears to be changing as machine stitching process technologies improve.

Second, the emergence of thermo-moulded balls in recent years has shown that high quality machine-made footballs can compete in terms of shape, quality, aerodynamics and performance with the high-end hand-stitched balls. Thermo-moulded balls were initially produced under patent by Adidas's supplier Molten in Thailand. More recently Adidas developed the newly patented Jabulani ball with a new first tier supplier in China. Following Adidas, Nike has developed its own variant of thermo-moulded footballs. In terms of process technology know-how, the key feature of thermo-moulded football production is that it requires capability and know-how related to injection moulding techniques and is thus quite different as a production line from a traditional machine-stitching assembly line. Thus, it is interesting to note that when Adidas shifted its sourcing of thermo-moulded footballs from Molten in Thailand to a new supplier in Shenzhen, China it turned to a firm that had not previously manufactured footballs, but was a long term first tier supplier to Adidas of goal keeper gloves and shin guards using injection moulding technologies.

Third, the leading brands, in particular Nike but also Adidas, have promoted the adoption of lean manufacturing principles by their football manufacturing suppliers. The adoption of lean manufacturing in football production began in 2009 when Nike reformed its internal organisational structure to integrate its compliance-related functions with its sourcing practices. This led to the view that the adoption of lean manufacturing could 
result in process efficiency for producers through the reduction of waste and the adoption of just-in-time practices, as well as improve outcomes for workers with enhanced productivity and higher wages. Locke and Romis (2007) illustrate the adoption of lean manufacturing practices by Nike in its ties with apparel suppliers in Mexico. As one of our key informants in Nike stated:
"lean philosophy and lean principles are now driving the logic of all sourcing strategies [in Nike]. If the worker can be empowered - to stop the production lines - then they are more likely to be able to report abuse as well as ensure that the issues of compliance failure do not arise. This also enhances value - and creates value." (Nike interview, Guangzhou, May 2010)

Interviews with Adidas also suggested that lean production was a key factor in process organisation within the supply chain. As one Adidas key informant reported:

\begin{abstract}
"We are definitely moving towards lean production as a way to enhance efficiency. Lean manufacturing is reducing waste, reducing inventories, reducing manufacturing time and reducing 'ways', people in the lines have to have as short as possible movements." (Adidas Interview, Guangzhou, May 2010)
\end{abstract}

While the shift to lean production for Nike appeared to be linked to improving, and internalising, compliance more centrally into its sourcing practices, we were able to observe changes in the organisation of production by first tier suppliers for both brands. Thus, for example, Adidas' main supplier in China reported that its main production line operated on lean principles. Rather than assembly line manufacturing, there were cell-based production teams that included panel stitchers who worked alongside workers producing the final bladder, threading the bladder, and the screen printing of panels. Individual workers appeared to be doing two to four tasks within each given process with inputs provided every few minutes. This shift to lean manufacturing took over two years for the supplier to implement and led to cost savings in costs through reduced inventories and waste. The supplier acknowledged that Adidas played a key role in this transition, in providing know-how and support. At the same time they faced substantial resistance from workers who were not keen to move to group-based units and incentive systems (supplier interview, Jiangxi Province, May 2010).

\title{
6 Upgrading, learning and GVC ties in the global football manufacturing industry
}

The football sector has seen some significant patterns of upgrading in terms of new products and process technologies over the past 15 years. The use of new materials has enhanced the performance of footballs, while changes to the structure of the ball, and the ways in which it is assembled have also transformed the industry itself. The sources of knowledge behind these changes have been mixed. This section explores the relationship between GVC governance and patterns of learning and capability acquisition. As discussed earlier, one of the limitations of the GVC approach is its relatively weaker understanding of the processes by which upgrading comes about (Morrison et al., 2008). Understanding upgrading requires an analysis of not only intra-chain relationships, but also intra-firm and extra-chain ties. 
In an industry where the brands are so dominant, the leading brands have been an important source for knowledge-changing innovations. The development of the non-stitched high performance thermo-moulded ball with fewer panels, emerged, for example, from the research and development efforts of Adidas. However, the development of the process technologies to mass produce the thermo-moulded product required close interaction between Adidas and its first tier suppliers, initially Molten in Thailand and subsequently Long Way in Shenzhen, China. Similarly, other brands have also actively engaged in new product development, especially in the use of new PU and TPU materials that have improved ball performance. And more recently, the brands have been the leading motivators that have encouraged suppliers to adopt lean management principles in their production organisation. However, to successfully implement these changes has also meant interacting with suppliers that have capabilities and engage in what Lall (1992) referred to as 'technical effort'.

Thus, in the development of the new thermo-moulding techniques to produce the high bonded footballs, both Adidas and Nike have developed ties with key suppliers in China that are organised around modular and relational forms of GVC governance. For this supplier capability is critical. In the context of thermo-moulding, the key suppliers have to have access to capabilities in new process technologies associated with working with resins, with injection moulding and with heat treatments that were not found in traditional machine stitched football factories. In the case of Adidas this has meant building links with a key supplier that did not traditionally manufacture footballs but had the necessary capabilities for developing process techniques in thermo-moulding.

At particular moments, in certain areas of process upgrading it has been the suppliers and not the brands that have driven the change. The development of mechanised stitching, for example, came about through the technological efforts of the Taiwanese owned firm Top Ball which in 1997 pioneered the know-how and the capabilities to machine-stitch the 32 panel ball, and to build effective machine stitching assembly lines in its Dongguan factory. This was a radical transformation that revolutionised the football sector in China and allowed China to substantially increase its global market share. The rapid spread of know-how and capabilities around machine stitching came about as many workers and managers from Top Ball moved to other factories, or 'graduated' into setting up their own units. Adidas only began sourcing machine stitched balls for the first time from Top Ball in 1998. Top Ball, which has now largely relocated within China and established Smart Ball, is Adidas' main global football supplier. The nature of GVC ties between Top Ball/Smart Ball and Adidas are clearly relational. Adidas, for example, encouraged and assisted Smart Ball in adopting lean management practices in production.

These patterns of technological change have been critical to enhancing China's position within the industry. Interestingly, interviews with key respondents and producers indicated that there were no forms of extra-chain relationships that drove the process of technological learning and the acquisition of capabilities in China. There were no links to technology institutes or to external public sector research and development agencies. Thus there appears to be no specific regional or national innovation system that motivated, or promoted, the process of upgrading and capability development in the Chinese football manufacturing sector.

Yet, the nature of the chain itself has begun to alter. One of the key points raised by all the brands interviewed was the extent to which they had begun to consolidate their supply chains. Adidas, for example, now uses only two football suppliers in China. One 
firm to produce all its requirements for machine stitched balls and another for its thermo-moulded footballs. Similarly it uses two suppliers in Sialkot to provide its demand for hand stitched balls. The rationale for this was clearly stated by our Adidas respondent as follows:

"Shrinking the supply base also has to do with relationship, trust, costing,
quality - all these parameters are important. It is better to have a consolidated
supply base. You know the supplier for a long time, you know their capability
to innovate, to have quality etc. This is good for us and for them."
(Adidas Interview, Guangzhou, 11 May 2010)

Nike has done the same. It has one main supplier for hand-stitched balls from Sialkot and four suppliers from China. Of the four Chinese based firms, one is also Adidas's main supplier. Each of the four firms have distinct product lines for Nike - from machine stitched, hand stitched, laminated and its new hybrid thermo-moulded balls. As with Adidas, Nike has one preferred 'technology innovation partner'. This firm not only produces the Nike's top end hand stitched footballs (which it formerly used to source from Sialkot), but also works with Nike in developing its own hybrid thermo-moulded product.

The consolidation of the supply base also implies lower governance costs in terms of managing the chain, especially on issues of compliance. All the core suppliers are firms with which the brands have developed long standing relationships and have a good assessment of their capabilities and practices. Moreover, as the supply base narrows, the capacity of the supplier becomes critical. It is not surprising therefore, that Adidas's main supplier for machine-stitched balls is the largest single football manufacturing factory in the world, employing 7,200 workers and producing 3 million inflated balls a month of which nearly two million are footballs (supplier interview, Jiangxi, May 2010). Similarly, Adidas' main supplier of hand stitched balls in Sialkot has a production capacity of 500,000 balls a month and employs 1,200 workers within its main factory as well as a further 4 to 5,000 workers, who work for independent contractors in the supplier's 75 dedicated stitching centres in and around Sialkot. It claims to be the largest hand-stitching football manufacturer in the world (supplier interview, Sialkot, March 2008).

Product and associated process upgrading in footballs, in terms of the moves towards machine stitching and thermo-moulding, is primarily observed in China. As a consequence, for the leading brands, the nature of GVC ties have begun to change in their sourcing arrangements from China. Rather than simply captive relationships, these ties are marked by relational as well as modular arrangements that recognise the capabilities of suppliers, and thus their importance to the brands. But this raises two questions, first, what are the implications for learning, upgrading and GVC governance in Pakistan? Second, what about other buyers, to what extent do they display similar practices in terms of GVC governance and learning processes as seen with Adidas and Nike?

In the context of Pakistan we see little evidence of product or process upgrading within the Sialkot football cluster. The dominant form of production remains hand-stitching. This continues in the main to be done by independent sub-contractors who work for specific football manufacturers. The only exception to this is Nike's main supplier which, on the insistence of Nike, has adopted a factory based model of production organisation with all production related activities undertaken within the 
factory premises. The primary motivation for this is the continuing concerns related to labour standards compliance, and the need for the major brands to minimise costs associated with damaging allegations on non-compliance on labour standards.

There was at the time when this research was undertaken, little evidence of Pakistani producers acquiring machine stitching technologies or developing thermo-moulding techniques ${ }^{8}$. This would require new forms of capabilities and skills which are currently not to be found within the cluster. Similarly, local cluster-based institutions providing technical support, know-how, skills or research and development inputs to the Sialkot football manufacturing cluster are extremely limited. Hence, GVC ties in Sialkot remain largely captive in nature with power resting in the hands of the major brands and buyers. The ties remain captive because of the on-going concerns around compliance, although for some of the major brands (Adidas for example) ties with key suppliers may be moving into more relational arrangements. Learning and knowledge acquisition will probably require greater engagement between the suppliers and the brands. It would also require suppliers investing in enhancing their own capabilities, and raising human capital as well as investing in new process technologies.

With respect to the second question, there are a number of other buyers in the football sector who do not operate in similar ways to the leading global sports goods brands. These include non-sports brands that demand promotional balls, major global retailers as well as a wide array of traders, wholesalers, distributors and football clubs. For such buyers close ties with suppliers is less critical. These buyers are not sourcing the top end match balls, but instead more standardised and relatively lower quality products. For this they do not need modular or even relational forms of chain governance. In some cases, governance arrangements are defined by market-relationships with short-term ties with suppliers. What is often more important is the need for suppliers to meet economies of scope - that is to say to supply not just footballs but also a wider range of related sports goods. Thus, many of the football firms interviewed in Guangdong province were noted for their ability to produce a range of inflatable balls as well as non-ball sports products and accessories. Such firms, however, rarely dealt with the leading global sports goods brands. Again, this places a pressure on the Sialkot cluster. Its product line is almost exclusively in footballs, and there is limited evidence of scope economies to be observed in the cluster.

\section{Conclusions: labour standards, technological upgrading and the shifting geographies of production}

The global football industry is noteworthy for a number of reasons. It has grown rapidly over the past decade. It has also seen a significant shift in terms of the locations of production and the emergence of new end markets. China has consolidated its position as the world's largest football manufacturer, taking market share from Pakistan the world's second biggest producer. In China production is largely concentrated in two regions, marked by quite different types of firms and products. Supplier consolidation by the leading brands has also meant the growing significance of large OEM producers in China. In Pakistan production is solely located in one cluster that supplies both the leading brands as well as diverse end markets. The global football industry is dominated by well known international sports goods brands. These too have consolidated their 
positions with Nike and Adidas the dominant players. The football manufacturing sector has drawn a great deal of attention in recent years from both the media and academics for challenges related to labour standards, in particular child labour. At the same time, there have been important areas of technological upgrading within the sector, in terms of product development (new types of more aerodynamic footballs) as well as the use of new process technologies (from machine stitching to thermo-moulding).

The GVC framework provides a useful tool to map the global industry and to assess how the chains are governed and organised by the major brands. But the framework is relatively weak in terms of providing a handle on how technological upgrading takes place within the sector. For that a better understanding of firm level capabilities and learning processes is required. As the paper has shown, the changing patterns of GVC governance exercised by the leading brands in their sourcing arrangements from OEM suppliers in China and Pakistan take account of the growing importance of supplier capabilities, and the role of some key first-tier suppliers as critical technological and innovation partners.

The sector has also been marked by challenges in terms of social compliance. These challenges have been met in part by more stringent monitoring of the chain, through codes of conduct and internal and independent audits as well as through cluster based monitoring on child labour undertaken in Sialkot by independent international, and now local, agencies. Pressures on social compliance have altered the nature of production in Pakistan, with the leading brands no longer willing to source from suppliers who sub-contract aspects of production to home-based locations. Thus, in the Sialkot cluster one can observe the rise of increasingly more regulated forms of labour organisation, in designated stitching centres as well as in integrated large factories. Although not as acute a pressure as that faced by Pakistani producers, labour standards compliance has been an issue in China as well, and this is one factor behind the greater consolidation of first tier suppliers in China by the leading brands.

A number of authors have recently argued for greater attention to be paid to the links between economic and social upgrading within GVC ties (see, for example, Locke et al., 2009; Barrientos et al., 2010; Milberg and Winkler, 2010; Mayer and Pickles, 2010). Some of this new research has sought to understand whether engagement in GVC and GPN have led not only to higher levels of productivity and employment growth, but also whether and how this has improved outcomes for workers, especially in terms of wages, working conditions and, more broadly, labour rights. This raises important academic and policy questions for the global football manufacturing industry. What consequences arise for local producers and workers from the twin challenges on labour standards compliance and technological upgrading? In particular, what are the implications of this for the Pakistani football manufacturing industry as it confronts the growing competitiveness of China? This calls for further research.

The Pakistani football industry has managed to confront the substantial challenge it faced on child labour during the mid 1990s. This required both local joint action within the cluster as well as international interventions by the global brands, NGOs and by international agencies. While the Nike pull-out of 2006 underlines the continuing vulnerability for the Sialkot cluster to challenges on social compliance, there is evidence to suggest that within the cluster larger producers and key suppliers to the major brands have managed to retain their positions, and even grow. It is less clear as to the outcomes for workers, especially poorer and more marginalised segments of the 
football manufacturing workforce. The conclusion that emerges is that social compliance is a necessary but insufficient condition to compete in the global football industry and supply the major global brands. That requires technological as well as social upgrading.

It is apparent that in terms of the technological upgrading within the global football sector, Sialkot has seen little evidence of new product development or shifts from hand stitching to mechanised forms of production. This has implications for the local industry and its ability to retain its global position. Sialkot continues to hold a niche for high quality premium hand stitched production, but at the same time improvements in machine stitching in China, the developments in more aerodynamic thermo-moulded footballs produced in China and the presence of high quality hand stitching has meant that Sialkot's market niche is being eroded. To respond to this the cluster needs to upgrade. This requires technological effort at the level of individual firms and for the cluster as a whole. This will not be easy.

The Sialkot cluster and the firms within it have to develop capabilities in a number of areas. First, they need to acquire improved capabilities in materials, especially in terms of the high end PU and TPU products that are being developed to improve the dynamics of footballs. Second, they need to acquire new capabilities in the realm of process technologies and production organisation. This implies developing the capabilities to undertake machine-based stitching. Acquiring such capabilities not only requires the acquisition of new technologies but also the development of new, and relatively alien, skills and ways of working for the cluster. For example, most of the Sialkot cluster's hand stitchers are poorly educated and often illiterate, and work from a crouching position close to the ground. Machine stitching implies working on seated work benches along mechanised production lines. This means not only new technology but also new forms of tacit knowledge and some degree of literacy and numeracy skills. This calls for extensive (re-)training of workers in Sialkot. Meeting the challenge on human capital is even more critical if the cluster is to regain its quality niche and manufacture thermo-moulded footballs. That requires an understanding of injection-moulding technologies, the use of resins and also heat processes within manufacturing. It is unlikely that this technology can be simply bought of the shelves. For it to be effectively developed and implemented within the Pakistani context new aspects of firm and worker level capabilities need to be developed within the cluster. This requires external extra-chain interventions, especially through local cluster-based institutions, as well as closer relationships within the GVC for effective learning to take place. In particular it calls for strategic and targeted policy support on technological upgrading and learning.

Finally, further research is needed to better understand the outcomes of these developments in social compliance and technological upgrading for workers both in Pakistan and China. What groups of workers have benefited from the changes brought about by product and process upgrading in the two countries, and how? How do working conditions and workers' benefits differ across the two countries, and distinct segments of the football sector? What consequences do the dynamic trends in global trade in footballs imply for football manufacturing workers in China and Pakistan? These questions call for more detailed and in-depth research that explores workers' experiences and draws on evidence from the workers' perspective. 


\section{Acknowledgements}

This paper draws on research conducted jointly with Peter Lund-Thomsen (Copenhagen Business School), Anita Chan (Sydney University of Technology) and Hong Xue (East China Normal University, Shanghai). Inputs provided by the research collaborators are gratefully acknowledged. The study was funded in part by the United Nations Industrial Development Organisation (UNIDO) and the Danish Social Sciences Research Council whose support is appreciated. This paper does not in any way reflect on the position of the respective funding bodies. The author has benefited from comments received on presentations drawn from this study at workshops and seminars in Manchester, Copenhagen and Vienna. The author is also grateful for comments received from reviewers and Peter Lund-Thomsen. The views presented here are those of the author and all errors remain his alone.

\section{References}

Bair, J. (2005) 'Global capitalism and commodity chains: looking back, going forward', Competition and Change, Vol. 9, No. 2, pp.153-180.

Barrientos, S., Gereffi, G. and Rossi, A. (2010) 'Economic and social upgrading in global production networks: developing a framework for analysis', Working Paper 2010/03, Capturing the Gains: Economic and Social Upgrading in Global Production Networks, University of Manchester, Manchester, UK.

Bell, M. and Albu, M. (1999) 'Knowledge systems and technological dynamism in industrial clusters in developing countries', World Development, Vol. 27, No. 9, pp.1715-1734.

Bell, M. and Pavitt, K. (1993) 'Technological accumulation and industrial growth: contrasts between developed and developing countries', Industrial and Corporate Change, Vol. 2, No. 2, pp.157-210.

Chan, A. (2003) 'A 'race to the bottom': globalisation and China's labour standards', China Perspectives, Vol. 46, pp.41-49.

Chan, C.K-C. (2010) The Challenge of Labour in China: Strikes and the Changing Labour Regime in Global Factories, Routledge, Abingdon.

Coe, N.M., Dicken, P. and Hess, M. (2008) 'Global production networks: realizing the potential', Journal of Economic Geography, Vol. 8, No. 3, pp.267-269.

Cook, P., Uranga, M.G. and Etxebarria, G. (1997) 'Regional innovation systems: institutional and organisational dimensions', Research Policy, Vol. 26, pp.475-491.

Edquist, C. (1999) 'Systems of innovation approaches - their emergence and characteristics', in C. Edquist (Ed.): Systems of Innovation: Technologies, Institutions and Organisations, Pinter, London and Washington.

Ernst, D. (2002) 'Global production networks and the changing geography of innovation systems: implications for developing countries', Economics of Innovation and New Technologies, Vol. 11, No. 6, pp.497-523.

Ernst, D. and Kim, L. (2001) 'Global production networks, knowledge diffusion and local capability formation: a conceptual framework', East-West Centre working paper 19, East-West Centre, Honolulu.

Fair Labour Association (2010) 'The independent assessment of football production in the supply chain of Shanghai Wande sporting goods company', Mimeo, available at http://www.fairlabor.org/images/stories/fairlabor/Wande\%20Summary_Final.pdf (accessed on 20 July 2010). 
Gereffi, G. (1994) 'The organization of buyer-driven global commodity chains: how United States retailers shape overseas production networks', in G. Gereffi and M. Korzeniewicz (Eds.): Commodity Chains and Global Capitalism, Praeger, Westport, CT.

Gereffi, G., Humphrey, J. and Sturgeon, T. (2005) 'The governance of global value chains', Review of International Political Economy, Vol. 12, No. 1, pp.78-104.

Gibbon, P. and Ponte, S. (2008) 'Global value chains: from governance to governmentality', Economy and Society, Vol. 37, No. 3, pp.365-392.

Global Sources (2006) Sports Balls - China Sourcing Report: Essential Sourcing Intelligence for Buyers, Trade Media Limited, Hong Kong.

Goldblatt, D. (2006) The Ball is Round: A Global History of Football, Viking, London.

Henderson, J., Dicken, P., Hess, M., Coe, N. and Yeung, H.W-c. (2002) 'Global production networks and the analysis of economic development', Review of International Political Economy, Vol. 9, No. 3, pp.436-464.

Humphrey, J. and Schmitz, H. (2002) 'How does insertion in global value chains affect upgrading in industrial clusters', Regional Studies, Vol. 36, No. 9, pp.1017-1027.

Husselbee, D. (2000) 'NGOs as development partners to the corporates: child labour stitchers in Pakistan', Development in Practice, Vol. 10, Nos. 3-4, pp.377-389.

Kaplinsky, R. (2005) Globalisation, Poverty and Inequality: Between a Rock and a Hard Place, Polity Press, Cambridge.

Khan, A. (2007) Power, Policy and the Discourse on Child Labour in the Football Manufacturing Industry of Sialkot, Oxford University Press, Karachi.

Khan, F.R., Munir, K.A. and Wilmott, H. (2007) 'A dark side of institutional entrepreneurship: soccer balls, child labour and postcolonial impoverishment', Organization Studies, Vol. 28, No. 7, pp.1055-1077.

Kolk, A. and Tulder, R.V. (2001) 'Multinationality and corporate ethics - codes of conduct in the sporting goods industry', Journal of International Business Studies, Vol. 32, No. 2, pp.267-283.

Lall, S. (1992) 'Technological capabilities and industrialisation', World Development, Vol. 20, No. 2, pp.165-186.

Locke, R.M. and Romis, M. (2007) 'Improving working conditions in global supply chains', MIT Sloan Management Review, Vol. 48, No. 2, pp.54-62.

Locke, R.M., Amengual, M. and Mangla, A. (2009) 'Virtue out of necessity: compliance, commitment and the improvement of labor conditions in the global supply chains', Politics and Society, Vol. 37, No. 3, pp.319-351.

Lund-Thomsen, P. and Khan, F.R. (2011) 'CSR as imperialism: towards a phenomenological approach to CSR in the developing world', Journal of Change Management, Vol. 11, No. 1, pp.73-90.

Lund-Thomsen, P. and Nadvi, K. (2010) 'Clusters, chains and compliance: corporate social responsibility and governance in football manufacturing in South Asia', Journal of Business Ethics, Vol. 93, pp.201-222.

Mayer, F. and Pickles, J. (2010) 'Re-embedding governance: global apparel value chains and decent work', Working paper 2010/01, Capturing the Gains: Economic and Social Upgrading in Global Production Networks, University of Manchester, Manchester, UK.

Milberg, W. and Winkler, D. (2010) 'Economic and social upgrading in global production networks: problems of theory and measurement', Working paper 2010/04, Capturing the Gains: Economic and Social Upgrading in Global Production Networks, University of Manchester, Manchester, UK.

Morris, L. (2007) 'Nike to buy the soccer-apparel maker umbro for $\$ 580$ million', the International Herald Tribune, October 24 , available at http://www.iht.com/articles/2007/10/23/bloomberg/bxnike.php (accessed on 12 July 2008). 
Morrison, A., Pietrobelli, C. and Rabellotti, R. (2008) 'Global value chains and technological capabilities: a framework to study learning and innovation in developing countries', Oxford Development Studies, Vol. 36, No. 1, pp.39-58.

Mytelka, L.K. (2000) 'Local clusters, innovation systems and sustained competitiveness'; INTECH Discussion paper series \#2000-5, Maastrict, The United Nations University Institute for New Technologies.

Nadvi, K. (2008) 'Global standards, global governance and the organisation of global value chains', Journal of Economic Geography, Vol. 8, No. 3, pp.323-343.

Nadvi, K. (2004) 'The effect of global standards on local producers: a Pakistani case study', in Schmitz, H. (Ed.): Local Enterprises in the Global Economy, Edward Elgar, Cheltenham.

Nadvi, K. and Halder, G. (2005) 'Local clusters in global value chains: exploring dynamic linkages between Germany and Pakistan', Entrepreneurship and Regional Development, Vol. 17, No. 5, pp.339-363.

Nelson, R.R. (1992) National Innovation Systems: A Comparative Analysis, Oxford University Press, Oxford.

Pun, N. (2005) 'Global production, company codes of conduct, and labor conditions in China: a case study of two factories', The China Journal, Vol. 54, pp.101-113.

Rugman, A. and D'Cruz, J. (1997) 'The theory of the flagship firm', European Management Journal, Vol. 15, No. 4, pp.403-412.

Sato, Y. and Fujita, M. (2009) 'Capability matrix: a framework for analysing capabilities in value chains', IDE Discussion Paper 219, Institute of Developing Economies, Tokyo.

Seigmann, K.A. (2008) 'Soccer ball production for Nike in Pakistan', Economic \& Political Weekly, Vol. 43, p.22.

Sturgeon, T. (2002) 'Modular production networks: a new American model of industrial organisation', Industrial and Corporate Change, Vol. 11, No. 3, pp.451-496.

Sum, N-L. and Ngai, P. (2005) 'Globalisation and paradoxes of ethical transnational production: code of conduct in a Chinese workplace', Competition and Change, Vol. 9, No. 2, pp.181-200.

Sun, Z. and Zhang, G. (2009) 'Beyond typologies of global value chain governance: the accumulation of technological capabilities', International Journal of Business and Management, Vol. 4, No. 1, pp.32-36.

Tokatli, N. (2008) 'Global sourcing: insights from the global clothing industry - the case of Zara, a fast fashion retailer', Journal of Economic Geography, Vol. 8, No. 1, pp.21-38.

UN Comtrade (2010) United Nations Commodity Trade Statistics, Online Database, Statistics Division, United Nations, New York, available at http://comtrade.un.org/db/ce/ceSnapshot.aspx?px=H1\&cc=950662.

UNIDO (2008) Diagnostic Study - Sports Goods Cluster of Sialkot, Pakistan, Lahore, UNIDO.

\section{Notes}

1 See for example, http://news.bbc.co.uk/sport1/hi/football/world_cup_2010/8743207.stm.

2 A total of 17 manufacturing firms were interviewed in China and 11 producers in Pakistan. In addition interviews were carried out with key respondents in the major brands including Nike, Adidas and Mitre-Pentland.

3 While the critical distinctions between the two concepts are noted, for the purposes of this paper which concentrates on vertical inter-firm relationships, the GVC framework will be used.

4 The UN Comtrade database reports trade figures for inflatable balls (product code 950662). This includes all types of inflatable balls including volleyballs, basketballs, rugby balls as well as footballs. 
5 This data includes all types of inflatable balls. Pakistan only produces footballs whereas China manufactures the full variety of inflatable balls (basketballs, volleyballs, rugby balls as well as footballs). Hence, within the sub-category of footballs Pakistan's share is somewhat greater than the figures reported here for inflatable balls would suggest.

6 This data comes from interviews conducted with manufacturers.

7 Child labour has also been a challenge for the Indian football industry clustered in and around the city of Jalandhar in the Indian Punjab. See Lund-Thomsen and Nadvi (2010) for a detailed comparative discussion of the pressures on child labour in football production in South Asia. This paper does not address the Indian case on the basis that India remains a minor player in global football manufacturing, accounting for only $2 \%$ of world football exports.

8 There is some indication that Adidas' main supplier in Sialkot has acquired thermo-moulding technologies and is developing, with Adidas, supply of thermo-moulded balls, see http://online.wsj.com/article/SB20001424052748703465204575207982953211828.html. 